\title{
World Bank will lend more money to India for AIDS
}

Based on talks with the World Bank that ended last month, the Indian government has announced that it plans to use one quarter of an anticipated $\$ 200$ million loan from the Bank for HIV and AIDS, to solidify its R\&D efforts in this field. The exact amount of the loan will be announced in August.

The money is a five year extension of the Bank's support for the AIDS situation in India and will be released when the existing loan of $\$ 89$ million draws to a close in March 1999. A further $\$ 50$ million will go to blood safety programs and hospital and community care schemes as well as to purchase medications for opportunistic infections, which was not possible under the conditions of the current loan.

Under a strategy devised jointly by the Department of Biotechnology and the Indian Council of Medical Research (ICMR), the $R \& D$ money will be divided between indigenous AIDS vaccine programs, the assessment of locally manufactured HIV diagnostic kits and development of vaginal microbicides. For the first time, the government will also launch a consolidated program of clinical trials in HIV patients-previous efforts have involved only herbal medicine tests. The new trials are aimed at determining cure and prophylaxis rates with different antiTB regimens.

In addition to basic research, funding will also be provided for economic research to evaluate expenses such as the cost of patient care and the impact of the epidemic on the workforce. A new center for epidemiology research will also be created.

Special emphasis will be placed on HIV/AIDS in women. "With half of HIV infections in females occurring among women of child-bearing age, we are primed for a pediatric AIDS crisis," says Vulimiri Ramalingaswami a former ICMR chief who is advising the New Delhi based National Aids Control Organization (NACO). Trials are planned to assess the minimum dose and duration of AZT treatment in pregnant women to prevent mother-to-fetus virus transmission. Research into the effectiveness of female condoms is also on the drawing board.

The Bank has also specified that 50 percent of the funds should go to non-governmental organizations (NGOs) for 'intervention projects' in targeted groups such as commercial sex workers and injectable drug users.

The Bank is perhaps the largest funder of AIDS prevention in the world. However, this section of the program may run into trouble because of a policy introduced in March this year that has divested NACO of its financial powers, meaning that it can no longer fund NGO AIDS-control efforts directly. NACO's future role will be to allocate funds to different states and let state governments determine NGO financing.

According to an associate of the secretary for health Kunwar Bahadur Saxena, the NACO restructuring is rooted in the new realization that AIDS will be a longterm problem for the country and responsibility for its control must rest with state governments. "The day has come for the states to treat AIDS as their problem and stop thinking that it is NACO's program," he told Nature Medicine.

"This is going to cause problems at least initially," says Mohammed Shaukat, NACO's public health specialist. "Most states are ill-equipped to monitor or evaluate the work of NGOs and established NGOs are not comfortable with state cells that do not know how to distinguish good guys from the bad."

A top NACO official confessed embarrassment that restructuring is taking place at a time when the Bank is preparing to put such a large amount of money into the system. He says that NACO should have long since prepared the state machinery to be autonomous in managing NGOs, "instead we let the state government turn to us for help on [AIDS] and now we suddenly ask them to take over from us. This is not midcourse correction, it is midcourse deterioration."

Shankar Choudhary, assistant professor of community medicine and coordinator of the NGO-AIDS group at the All India Institute of Medical Sciences in New Delhi warns that the new policy will lead to high quality NGOs dropping out of the system. In fact, Drishtikon-a well respected Delhi NGO-claims its work, which was until recently funded by NACO, has come to halt as a result of the changes. Director Sushma Sengupta alleges that although the Delhi AIDS cell is funding NGOs that only exist on paper, "it refuses even to accept our application for continuation of the project." A.K. Bansal, who heads the cell, denies this: "We are funding four NGOs at a total of $\$ 62,500$ and they all exist. Drishtikon refused to apply in the correct way."

The AIDS control program could also suffer due to shortage of manpower, claim NACO officials. Two months ago, Saxena fired five of the seven NACO consultants on the grounds that they were too old (above 62) and dismissed half of the support staff he thought were superfluous. With experienced consultants gone, NACO's clinical management and other technical support services have been eroded. Saxena was not available for comment.

Although local changes in public health policies did not affect the loan, India's recent nuclear testing might. Four projects that were due to go before the Bank's board last month to support India's renewable energy program have been placed on hold since the tests. While international sanctions against the nation have mostly affected aid for industrial development, World Bank officials would not rule out the possibility that social programs could also be affected. "It's not clear what's going to happen with projects in the pipeline," says Rebeca Robboy, the Bank's External Affairs Officer for South Asia. K.S. Jayaraman, NeW Dei.hi 